\title{
NARRATIVAS DE SUJEITOS COM DEFICIENCIA E ISOLAMENTO SOCIAL EM TEMPOS DE PANDEMIA
}

\author{
NARRATIVAS DE SUJETOS CON DISCAPACIDAD Y AISLAMIENTO SOCIAL EN \\ TIEMPOS DE PANDEMIA
}

\section{NARRATIVES OF SUBJECTS WITH DISABILITIES AND SOCIAL ISOLATION IN PANDEMIC TIMES}

\author{
Vanderlei Balbino da COSTA ${ }^{1}$ \\ Claudenilson Pereira BATISTA ${ }^{2}$ \\ Euler Rui Barbosa TAVARES ${ }^{3}$
}

RESUMO: A história no século XXI vem passando pelas mais diversas transformações sociais, culturais e religiosas, principalmente, no que concerne o comportamento humano. A presente reflexão elucida narrativas de Pessoas com Deficiência em tempos de pandemia e isolamento social causado por um fenômeno mundial caracterizado como Corona Vírus. A questão que suleou essa investigação foi: como está sendo o isolamento social das pessoas com deficiência em tempos de pandemia? Os objetivos foram: entender por meio das narrativas como está sendo o cotidiano das Pessoas com Deficiência em tempos de pandemia; identificar nas narrativas desses sujeitos, momentos de ansiedade, tenção e desconforto emocional que estão vivendo em seu isolamento social; analisar as narrativas de quatro sujeitos que estão vivendo o isolamento social em tempos de pandemia, provocado pela proliferação do Covid-19 (Corona Virus Disease / Doença do Corona Vírus 2019). A metodologia escolhida foi por meio de depoimento escrito, narrado por esses sujeitos em seu isolamento social. Os referenciais utilizados versaram sobre narrativas, memorias e (auto)biografia que narra o comportamento social desses em tempos de pandemia. As notas finais, claro, não conclusivas nos fizeram perceber que os sujeitos narram em seus depoimentos forte estágio emocional, tensões e medo desse fenômeno que está assustando o planeta.

PALAVRAS-CHAVE: Sujeitos com deficiência. Isolamento social. Pandemia.

RESUMEN: La historia del siglo XXI ha pasado por las más diversas transformaciones sociales, culturales y religiosas, especialmente en lo que respecta al comportamiento humano. La presente reflexión dilucida las narrativas de las personas con discapacidad en tiempos de pandemia y aislamiento social provocado por un fenómeno mundial caracterizado como el

\footnotetext{
${ }^{1}$ Universidade Federal de Jatai (UFJ), Jataí - GO - Brasil. Professor da Faculdade de Educação. Doutorado em Educação Especial (UFSCAR). ORCID: https://orcid.org/0000-0002-1330-747X. E-mail: vanderleibalbino@gmail.com

2 Secretaria Municipal de Educação, Manaus - AM - Brasil. Professor Secretaria Municipal de Educação. Doutorado em Educação (UFAM). ORCID: https://orcid.org/0000-0002-6015-4816. E-mail: batista.claudio@outlook.com

${ }^{3}$ Instituto Federal de Educação, Ciência e Tecnologias do Tocantins (IFTO), Palmas - TO - Brasil. Professor do IFTO. Mestre em Educação (UFT). ORCID: https://orcid.org/0000-0002-2889-7804. E-mail: euler.tavares@ifto.edu.br
}

RIAEE - Revista Ibero-Americana de Estudos em Educação, Araraquara, v. 15, n. esp. 3, p. 2471-2489, nov., 2020. E-ISSN: 1982-5587 
virus corona. La pregunta que cubrió esta investigación fue: ¿cómo es el aislamiento social de las personas con discapacidad en tiempos de pandemia? Los objetivos fueron: comprender, a través de las narrativas, cómo la vida cotidiana de las Personas con Discapacidad atraviesa tiempos de pandemia; identificar en las narrativas de estos sujetos, momentos de ansiedad, tensión y malestar emocional que están viviendo en su aislamiento social; Analizar las narrativas de cuatro sujetos que están experimentando aislamiento social en tiempos de pandemia, provocada por la proliferación de Covid-19 (Enfermedad por Virus Corona / Enfermedad por Virus Corona 2019). La metodología elegida fue a través del testimonio escrito, narrado por estos sujetos en su aislamiento social. Las referencias utilizadas fueron sobre narrativas, recuerdos y (auto) biografia que narran su comportamiento social en tiempos de pandemia. Las notas finales, por supuesto, no concluyentes nos hicieron darnos cuenta de que los sujetos narran en sus testimonios una fuerte etapa emocional, tensiones y miedos ante este fenómeno que atemoriza al planeta.

PALABRAS CLAVE: Sujetos con discapacidad. Aislamiento social. Pandemia.

ABSTRACT: History in the 21st century has been going through the most diverse social, cultural and religious transformations, especially with regard to human behavior. The present reflection elucidates narratives of People with Disabilities in times of pandemic and social isolation caused by a worldwide phenomenon characterized as Corona Virus. The question that covered this investigation was: how is the social isolation of people with disabilities in pandemic times? The objectives were: to understand, through the narratives, how the daily life of People with Disabilities is going through pandemic times; identify in the narratives of these subjects, moments of anxiety, tension and emotional discomfort that are living in their social isolation; to analyze the narratives of four subjects who are experiencing social isolation in times of pandemic, caused by the proliferation of Covid-19 (Corona Virus Disease / Corona Virus Disease 2019). The chosen methodology was through written testimony, narrated by these subjects in their social isolation. The references used were about narratives, memories and (auto) biography that narrates their social behavior in times of pandemic. The final notes, of course, not conclusive made us realize that the subjects narrate in their testimonies a strong emotional stage, tensions and fear of this phenomenon that is frightening the planet.

KEYWORDS: Subjects with disabilities. Social isolation. Pandemic.

\author{
"O mundo não é mais o mesmo \\ Em que eu nasci \\ Mas eu continuo curando a tristeza \\ Com a beleza de uma canção \\ Por isso ainda canto o meu rock rool". \\ Nando Reis (2018).
}

\title{
Notas Iniciais
}

Das cavernas aos pés na lua, das caravelas ao Titanic, das asas deltas ao supersônico, tivemos os mais diversos momentos de evolução histórico-social na esfera planetária. 
Dos homens "bons, perfeitos e normais", em Esparta, aos "homens livres", em Atenas, do triunvirato aos escravos na Roma antiga, das invasões europeias à resistência dos índios ianomâmis na Amazônia, atualmente passamos pelos mais variados estágios de transformação política, social, cultural e até religioso, considerando as ações atitudinais e comportamentais dos seres humanos ao longo de séculos.

De lançados aos penhascos como obra demoníaca na Grécia Antiga, ao (Re)conhecimento da deficiência no século XVIII, vivemos os mais variados estágios de segregação, marginalização e exclusão social na humanidade ao longo de milênios. Frente ao exposto, Correia (1999), narra que desde a história antiga registra-se as políticas de exclusão de crianças com deficiência. O autor sublinha que em Esparta, as crianças defeituosas eram abandonadas nas montanhas. Por sua vez em Roma eram jogadas nos rios para não manchar a sociedade.

Ao longo da história, registra-se traços de preconceitos, estereótipos, discriminações e estigmas contra aquelas pessoas que fogem aos padrões de "normalidade e perfeição". Essas lembranças soam em nossa memória, aqui narradas por Souza (2007, p. 63) como:

Memória é escrita no tempo, um tempo que permite deslocamento sobre as experiências. Tempo e memória que possibilitam conexões com as lembranças e os esquecimentos de si, dos lugares, das pessoas, da família, da escola e das dimensões existenciais do sujeito narrador.

As palavras do autor nos despertam para a importância de narrar nossas experiências em tempos de isolamento social, guardadas na memória e que podem ou não serem expressadas no e durante a nossa trajetória pessoal.

Há registro na nossa memória narrada nesse excerto de texto que durante décadas, o tratamento aos diferentes, dessemelhantes, desviantes, sempre foi uma marca perversa da sociedade nas mais diversas épocas. O modelo de eugenia proposto se vivencia nos escritos de Bianchetti, (1995), ao pontuar que na sociedade espartana que valorizava guerra, a dança, ginastica, estética, a perfeição do corpo "forte e belo", era o grande objetivo de uma sociedade que se intitulava "sã, normal, bem constituída".

$\mathrm{O}$ isolamento social, imposto às Pessoas com Deficiência, obviamente provocado pela segregação nas culturas antigas se dava pelas práticas implementadas, sob a crença de que os não "perfeitos" precisavam ser eliminados porque não eram obra divina. Essa premissa é narrada por Misés (1977, p. 14), ao pontuar que:

Nós matamos os cães danados e touros ferozes, degolamos ovelhas doentes, asfixiamos recém-nascidos mal constituídos; mesmo as crianças se forem

RIAEE - Revista Ibero-Americana de Estudos em Educação, Araraquara, v. 15, n. esp. 3, p. 2471-2489, nov., 2020. E-ISSN: 1982-5587 
débeis ou anormais, nós as afogamos, não se trata de ódio, mas da razão que nos convida a separar das partes sãs aquelas que podem corrompê-las. Esse tratamento estigmatizante às Pessoas com Deficiência foi vivenciado durante séculos pela humanidade detentora de hábitos conservadores, costumes arcaicos e crença na perfeição.

No decorrer dos séculos, o tratamento destinado às Pessoas com Deficiência continuou sendo uma marca de exclusão, considerando que na Era Medieval, esses sujeitos eram associados a imagem do mau, atos de feitiçaria, sendo perseguidos e posteriormente mortos, uma vez que não podiam viver em sociedade. Em seus escritos Amaral (1990, p. 30-31), narra que nesta época aplicava-se a política do avis-struthio, que significa:

Enterrar a cabeça na areia, isolando o estranho, o deficiente, seja criando ativamente locais de confinamento, seja esperando que esse ser desconfortável tenha a gentileza de tornar-se invisível para os olhos sensíveis, recolhendo-se a sua insignificância, modestamente colocando-se em seu devido lugar, o mais longe possível dos cidadãos comuns.

Esse isolamento social, claro, em menor proporção, que as Pessoas com Deficiência estão vivendo atualmente em tempos de pandemia podem ser metaforizado, considerando que estamos, em relação aos demais, excluídos/desprovidos de acesso aos meios de comunicação, das tecnologias avançadas e das informações externas ao alcance dos nossos olhos, ao silêncio dos nossos ouvidos, ou as limitações físicas dos nossos passos.

Intencionamos nessas palavras, linhas, parágrafos, excertos de textos, narrar brevemente como está sendo nosso isolamento social, nosso recolhimento, enfim, nossos meses de exclusão vivendo hoje em uma casa ampla, confortável, porém ladeada de muros, impedido de circular livremente com medo desse inimigo invisível conhecido como Novo Corona Vírus. Fazemos isso na defesa de que "pesquisas realizadas com sujeitos em situação de exclusão devem ocorrer, principalmente porque tiram suas vidas e suas realidades do anonimato" (ROCHA; REIS, 2020, p. 886).

Pensamos ser necessário pontuar que para Queiroz (1991, p. 19), narrativa é: "O relato do narrador sobre a sua existência através do tempo, tentando reconstruir os acontecimentos que vivenciou e transmitir a experiência que adquiriu". Testemunhamos nesses relatos nossos minutos, horas, dias, semanas, meses, que estamos tentando viver e conviver com a ideia do isolamento social, claro, necessário, porém difícil de suportar.

A questão que suleou essa investigação foi: como está sendo o isolamento social das Pessoas com Deficiência em tempos de pandemia? Nesse sentido, intencionamos demostrar como é o cotidiano das Pessoas com Deficiência em tempos de pandemia, em especial, quando

RIAEE - Revista Ibero-Americana de Estudos em Educação, Araraquara, v. 15, n. esp. 3, p. 2471-2489, nov., 2020. E-ISSN: 1982-5587 
por medo ou precaução nos isolamos, recolhemos, limitamos a conviver em espaços sem contato com idosos, crianças, colegas, escolas, lazer, gente.

Os objetivos neste processo investigativo foram: entender por meio das narrativas escrita como está sendo o cotidiano das Pessoas com Deficiência em tempos de pandemia; identificar nas narrativas desses sujeitos, momentos de ansiedade, tensão e desconforto emocional que estão vivendo em seu isolamento social; analisar as narrativas escritas de quatro sujeitos que estão vivendo o isolamento social em tempos de pandemia, provocado pela proliferação do Covid-19 (Corona Virus Disease /Doença do Coronavírus 2019).

Nossa opção nesta investigação foi pela pesquisa qualitativa. Nesse sentido, lançamos mão das narrativas de sujeitos com deficiência no intuito de identificar como esses estão vivendo o isolamento social em tempos de pandemia. Desse modo, utilizamos como técnica a abordagem biográfica, aqui enunciada por Souza (2006, p. 39), ao acentuar que "a abordagem biográfica tanto é método, porque logrou no seu processo histórico vasta fundamentação teórica, quanto é técnica, porque também gozou de conflitos, consensos e implicações teóricometodológicas sobre a sua utilização".

Lançamos mão das linhas escritas abaixo para narrar um pouco da história das Pessoas com Deficiência em tempos de isolamento social. Apoiamo-nos em Moita (1995, p. 113), ao expressar que na "(Auto)biografia, cada pessoa mobiliza seus conhecimentos, os seus valores, as suas energias, para ir dando forma a sua identidade, no diálogo com os seus contextos". Afinal, "a identidade não é algo imutável nem externo, que possa ser herdado ou adquirido. Ela é compreendida, historicamente, como um processo em construção na vida de uma pessoa" (SENA; ALBUQUERQUE, 2020, p. 1588). Daí, urge a necessidade de falar de nós, sobre nós, em especial, em momento de isolamento social ao qual fomos submetidos.

Pensamos ser necessário afirmar que a (auto)biografia narrada nesses excertos de texto reflete a vida das Pessoas com Deficiência isoladas, recolhidas em tempos de pandemia, sem poder circular livremente, ir ao parque, ao trabalho, a escola estudar.

Ao mencionar essa narrativa autobiográfica, apoiamos nas palavras escritas de Bueno (2002, p. 20), ao narrar que a:

autobiografia é uma microrrelação social. Aquele que narra sua história de vida sempre narra para alguém, ou seja, no processo de elaboração de sua narrativa há sempre a tentativa de uma comunicação, mesmo que seja com um interlocutor imaginário, como é o que muitas vezes acontece com os diários íntimos. 


\section{Momentos Reflexivos}

Ao longo de décadas, lutamos para sair do isolamento social, dos processos segregacionistas, da marginalização que nos excluiu durante séculos. Passamos pela institucionalização (APAES, Pestalozzi, IBC, INES, asilos, sanatórios), dentre outras que nos acolhiam, sei lá, com pena, dó, piedade, cuja intenção era isolar, separar e segregar todos que eram diferentes dos padrões impostos pela sociedade.

A partir da década de 1960 no Brasil, fomos "integrados nas escolas", claro, isolados, em salas separadas, longe dos demais que a sociedade erroneamente chama de "normais". Ao se referir a inclusão é profícuo assinalar que já se passaram três décadas que gestores, docentes e as Pessoas com Deficiência estão discutindo os processos inclusivistas, uma vez que na Era da Inclusão, a intenção precípua é a de que a sociedade possa se adaptar para nos receber com qualidade nas escolas e em todos os espaços sociais.

A problemática que enfatizamos nessa pesquisa diz respeito ao nosso isolamento social, bem como, a nossa convivência em tempos de pandemia. Nesse sentido, utilizaremos da (Auto)biografia para narrar nossa própria história. Para tanto, lançamos mão da memória partilhada por Halbwachs (1990), como algo que faz parte de um processo social em que os indivíduos não são vistos como seres isolados, eles interagem ao longo de suas vidas a partir de estruturas sociais determinadas. Assim, apoiamos em Clandinin e Connelly (2011), ao acentuar que experiências são as histórias que as pessoas vivem, e no contar dessas histórias se reafirmam. Modificam-se e criam novas histórias.

Nos espaços formativos, nos quais estamos inseridos, convivemos com as diferenças. Por meio da educação (Re)conhecemos o outro, o diferente, o desviante no espaço escolar. Ao se referir as lembranças, memórias e depoimentos expressas nessas narrativas, apoiamos em Catroga (2001, p. 46), ao pontuar que:

A memória é, mais que um mero registro, objetiva-se em uma narrativa coerente que, em retrospectiva, doméstica ou aleatório, ou casual, os efeitos perversos do real passado quando este foi presente, atuando como se, no caminho, não existissem buracos negros deixados pelo esquecimento.

Ainda perdura na nossa memória traços da exclusão social que vivemos a três décadas. Paira no nosso imaginário período de segregação que fomos acometidos durante anos nas instituições filantrópicas. Hoje, em pleno século XXI, anos 2020, pouco falamos em exclusão/segregação/marginalização, porém, metaforizamos novamente esses períodos quando somos de novo levados a nos recolher em nossas casas, temendo esse fenômeno. Essa memória

RIAEE - Revista Ibero-Americana de Estudos em Educação, Araraquara, v. 15, n. esp. 3, p. 2471-2489, nov., 2020. E-ISSN: 1982-5587 
que nos faz viver novamente esse isolamento social é lembrada por Amado, (1995, p. 132), ao acentuar que:

a memória torna as experiências inteligíveis, conferindo-lhes significados. Ao trazer o passado até o presente, recria o passado, ao mesmo tempo em que o projetando futuro; Graças a essa capacidade da memória de transitar livremente entre os diversos tempos, é que o passado se torna verdadeiramente passado, e o futuro, futuro.

Janaína Amado nos faz refletir sobre as lembranças presentes na nossa memória, expressa nas narrativas que fazemos quando lembramos do passado, vivemos o presente e até projetamos o futuro, claro, inserto, porém necessário ser programado.

\section{Dialogando com sujeitos com deficiência em tempos de pandemia}

A presente investigação foi realizada com quatro sujeitos com deficiência em três regiões do Brasil. Flor: 26 anos, solteira, graduanda em pedagogia em uma Universidade Pública Federal, surda congênita. Margarida: 41 anos, casada, mãe, psicóloga, mestre em educação, professora em uma instituição de ensino superior, deficiente visual. Rosa: 30 anos, casada, mãe, pedagoga, comerciante, deficiente física. Lírio: 46 anos, casado, pai, graduado em ciências Jurídicas, mestre em educação, professor em um Instituto Federal de Educação deficiente visual.

Ao nos dirigirmos aos sujeitos com deficiência através de e-mail, pedimos à eles que narrassem por escrito como está sendo seu período de isolamento social em tempos de pandemia. Justificamos a utilização desse procedimento metodológico, considerando a necessidade de se manter o isolamento e os cuidados com os sujeitos envolvidos na pesquisa. Para tanto, enviamos a eles um Termo de Consentimento Livre Esclarecido (TCLE), no qual os mesmos autorizaram a publicação de suas narrativas.

No intuito de preservar a identidade dos sujeitos com deficiência, decidimos em comum acordo, nomeá-los com pseudônimo de plantas. Assim, os sujeitos foram identificados como: FLOR; MARGARIDA; ROSA; LÍRIO.

Os excertos de textos abaixo, são trechos narrados pelos quatro sujeitos com deficiência que participaram da pesquisa. Ressaltamos que as narrativas serão analisadas, considerando os depoimentos desses durante seu recolhimento e isolamento social em suas residências.

Nas palavras, linhas, parágrafos, páginas que se seguem, lançamos mão das narrativas para falar brevemente da situação que vive as Pessoas com Deficiência em tempos de isolamento social, principalmente, quando referimos à educação, diferença e deficiência. 
Enquanto deficiente visual, sentimos na pele o que os diferentes/deficientes estão vivendo atualmente, em especial, quando somos obrigados a nos recolhermos em nossas casas temendo esse fenômeno chamado Corona Vírus.

Narrar a história das Pessoas com Deficiência em tempos de isolamento social, em especial, quando se refere a pandemia, não se constitui uma tarefa fácil, até porque, nunca foi fácil conviver de forma harmônica com os sujeitos que não ouvem os efeitos da sonorização externa aos seus ouvidos; não veem a exibição das imagens à sua frente; não andam livremente pelos vários espaços. Nesse emaranhado universo de relações ladeado pelo mundo subjetivo das narrativas, apoiamos em Benjamin, (1994, p. 221), para dizer que:

O narrador figura entre os mestres e os sábios. Ele sabe dar conselhos: não para alguns casos, como o provérbio, mas para muitos casos, como os sábios, pois pode recorrer ao acervo de toda uma vida, uma vida que não inclui apenas a própria experiência, mas em grande parte a experiência alheia.

Nesse contexto, lançar mão das narrativas nesses registros significa dizer que vidas, histórias, relatos, depoimentos, precisam ser contadas, evitando, portanto, que caia conforme alerta Catroga (2001), "No buraco negro do esquecimento".

\section{Flor}

Flor narra em seus escritos que:

O cotidiano tá complicado, muito tempo dentro de casa, comendo demais, sem fazer exercícios, sem foco pra estudar tem dias, tem dias que é tranquilo, tem dias que não é assim (vai indo). Desse modo, nessas poucas linhas narro como está sendo meu periodo de isolamento social em tempos de pandemia, uma vez que é muito ruim, com poucas opções de lazer, bem como cai no esquecimento de uma vida agitada com muitas tarefas para fazer em meio a tantas complexidades de incerteza, procuro as orações e acreditar que dias melhores virão.

Busco desvendar os mistérios que a vida nos oferece, observa-se que o cotidiano está complicado, por ter que ficar muito tempo em casa, fazendo lanches desnecessários tão pouco sem atividades fisicas, causando um desconforto fisico e emocional. Há sucessões de medo, angustias, incertezas e fraquezas enfim diante de tudo me perco por completa em meus pensamentos e me pergunto quão somos pequenos e frágeis perante uma pandemia, fico aqui imaginando dias e meses passaram de isolamento social e percebo que estou perdendo a estabilidade das atividades do dia-a-dia como foco em meus estudos.

Em nossa análise, pensamos que narrar o isolamento social, o cotidiano das Pessoas com Deficiência em tempos de pandemia, significa dizer que estamos vivendo em situação prisional, na medida em que tememos sair de casa para ir ao mercado, à farmácia, à praça, aos parques, 
enfim, cuidar dos nossos compromissos de forma segura, por que, temos medo desse inimigo invisível que o mundo está comentando: o Novo Corona Vírus. Nesse sentido, fomos levados a nos isolar, recolher, segregar, enfim, conviver em um cotidiano conceituado por Certeau (1994, p. 31), como:

[...] o cotidiano é aquilo que nos prende intimamente a partir do interior. Não se deve esquecer este 'mundo memória', segundo a expressão de Béguy. São o mundo que amamos profundamente, memória olfativa, memória dos lugares da infância, memórias do corpo, dos gestos da infância, dos prazeres.

Nessa perspectiva, tornamo-nos presos, não pela falta de liberdade, mas por uma condição de pandemia que vem assolando o planeta em 2020.

Flor, prossegue narrando:

Eu tinha ansiedade e crise de pânico, depois da pandemia piorou e aumentou. Meu cotidiano já não era tão fácil, por ter sido diagnosticada com crise de ansiedade e pânico, bem como agora percebo que estou sofrendo com os noticiários televisionados e redes sociais, confesso que a imprevisibilidade de tempo presente e futuro, causam aumento significativo das crises que foram mencionadas anteriormente.

Nossa entrevistada, narra seu cotidiano fazendo menção aos momentos de angústia, tensão e desconforto que está vivendo nesses novos tempos, a que fomos obrigados a nos submeter.

Outro aspecto importante que merece destaque:

sou medicada, uso de medicamento contínuo, às vezes não consigo me controlar com tantas notícias ruins, quando me sinto entristecida procuro pensar que posso fazer algo de bom para meus colegas surdos. Daí surgiu à ideia de fazer vídeos informativos sobre o Novo Corona Virus.

Flor procura em sua narrativa confortar-se frente o cenário que estamos vivendo, por exemplo, fazendo vídeos e compartilhando com seus colegas surdos que estão na mesma condição que ela.

“O nosso cotidiano é tenso, só ficamos em casa, cuidando da limpeza, cuidando dos estudos, claro, pouco, pouco não muito. A vida dos surdos é marcada pelas mudanças em seu cotidiano". Em sua narrativa, Flor destacou que se não fossem as redes sociais, a vida dos sujeitos surdos seria muito difícil. Nossa entrevistada aponta em seu depoimento a importância das tecnologias, caracterizada por Radabaugh (1988): historicamente, a expressão tecnologia assistiva surgiu pela primeira vez em 1988 nos Estados Unidos, como termo jurídico aprovado pela legislação americana visando garantir direitos das Pessoas com Deficiência.

RIAEE - Revista Ibero-Americana de Estudos em Educação, Araraquara, v. 15, n. esp. 3, p. 2471-2489, nov., 2020. E-ISSN: 1982-5587 
Prosegue Flor:

no momento, podemos dizer que as redes sociais que os surdos utilizam servem para melhorar nosso cotidiano, pois podemos comunicar com outros colegas surdos e ouvintes. Essa forma de interação e de comunicação entre a comunidade surda nos aproxima mais, mesmo quando estamos distantes.

ainda bem que existe celulares, notebook, vários aplicativos que permitem que fiquemos em casa, isolados, presos, sem poder sair, abraçar nossos amigos, ir passear, ir à escola estudar. Entendemos que estamos vivenciando uma nova experiência, pois, o perigo do Novo Corona Vírus deixa a gente temeroso, com medo de que esse vírus possa contaminar nossa família e as pessoas que gostamos.

Em sua narrativa, Flor, acentua:

Os habitantes do planeta partilham desta experiência, usam as redes sociais para se comunicar, pois existem tecnologias e aplicativos que permitem o diálogo entre colegas, professores e intérprete de libras para nos auxiliar. Como surda, não sei se posso dizer que sinto privilegiada ou desfavorecida. Nessa direção busco apropriar deste conhecimento avaliando que as redes sociais nos aproximam então posso dizer que sempre estivemos juntos virtualmente, embora separados, isolados, em casa, sem que possamos nos encontrar. É isso minha rotina, meu isolamento nesse cotidiano.

\section{Margarida}

Margarida, inicia sua narrativa destacando que seu maior desafio é:

Durante esse periodo de distanciamento social decorrente da pandemia pelo Novo Corona Virus, enquanto pessoa cega, meu maior desafio tem sido tentar acompanhar os diversos movimentos, causados pela crise social que o mundo vem passando nos últimos meses.

Em sua narrativa, Margarida, relatou que tem encontrado muitos desafios frente a crise mundial que se instalou no planeta com a deflagração da pandemia ao redor do mundo.

Em seu relato, nossa entrevistada, acentua que: "As mudanças que o planeta vem passando tem se mostrado fortemente presentes pela proposição de inúmeras lives. A meu ver, as reflexões suscitadas têm se mostrado instigantes e até necessárias ao fortalecimento humano em diferentes vertentes". Em seu depoimento escrito, Margarida enfatiza que as lives tem contribuído de certa forma para amenizar o estágio emocional que estamos vivendo em tempos de pandemia.

Narrar o momento de catástrofe como estamos vivendo no planeta, seguramente é ruim para todas as pessoas. Ao se referir as Pessoas com Deficiência, essas dificuldades se alargam cada vez mais. Isso se verifica, por exemplo, em relação as narrativas dos (surdos que tem 
dificuldades na comunicação escrita e na expressão oral; os sujeitos com deficiência física com limitações para se locomover nos diversos espaços; as Pessoas com Deficiência visual que utilizam as mãos para tocar e reconhecer os espaços ao seu redor).

As narrativas desses sujeitos nos fazem perceber que para eles, as dificuldades são maiores ainda, considerando que o mundo que nos ladeia não é inclusivo. Frente ao exposto, apoiamos em Marquesin e Ferragut, (2009, p. 27), para narrar as histórias desses sujeitos. Nesse sentido, assinalam: "A narração é o ato de contar histórias; é um processo formativo; transmite valores e conselhos e tem como principal características a sequencialidade". Sequencialidade essa que nos move e que requer de nós força para nos manter firme.

Margarida, expressa que as lives, se por um lado:

contribuem para o meu desenvolvimento pessoal e profissional, em vários momentos, ao acompanhá-las, percebo claramente, a ausência de recursos que as tornariam mais acessíveis às pessoas cegas, considerando que essas tecnologias ainda não são acessiveis para todas as pessoas, em especial, as com deficiência visual. Um fator que reforça minha concepção e que tem se apresentado com muita frequência durante minhas experiências como expectadora de diversas lives propostas, é a ausência quanto à descrição de imagens exibidas ao decorrer das abordagens, o que dificulta e algumas vezes, até inviabiliza a compreensão de determinados temas.

Margarida, faz ferrenhas críticas às tecnologias utilizadas, amplamente difundidas em tempos de pandemia. Enfatiza em seu depoimento que as tecnologias não são acessíveis para todas as pessoas, em especial, para sujeitos com deficiência visual, quase desprovidas desse direito, com independência e autonomia.

A queixa da nossa entrevistada, seria facilmente resolvida se os sites, blogs, Facebook, Twitter, utilizassem da audiodescrição, aqui descrito por Vilaronga (2010) como: a audiodescrição é um recurso tecnológico voltado as Pessoas com Deficiência visual que permite equiparar as oportunidades, bem como o acesso ao mundo das imagens e a eliminação das barreiras comunicacionais.

Por outro lado, acredito que dentre as diversas aprendizagens com as quais temos nos surpreendido diariamente durante esse periodo de intensas reflexões, a problemática apresentada, se passada adiante, poderá contribuir para a transformação social. No sentido de que a verdadeira inclusão se configure por meio da conscientização relativa à necessidade de que, independentemente de possuírem ou não alguma deficiência, os indivíduos sejam enxergados nas suas diferenças, bem como, nas suas reais necessidades e potencialidades.

Margarida em sua narrativa, revela que esse período tem de um lado, servido para aprofundarmos nossas reflexões frente o cenário que se desenhou neste ano. Por outro, temos a 
clareza que diante das possibilidades de que a pandemia não escolhe cor, raça, credo religioso, nações, pátria, países, temos a certeza de que não estamos livre dessa catástrofe que vem assolando o planeta.

\section{Rosa}

Rosa, abre sua narrativa afirmando que não está fácil conviver no:

Mundo no qual estamos vivendo hoje, realmente não está fácil, ainda mais, para uma Pessoa com Deficiência fisica que tem dificuldades para se locomover. Esses excertos de texto, vem em forma de narrativa de como está sendo minha experiência diante desses problemas, no qual o mundo inteiro está vivendo, uma pandemia devido ao vírus do Covid-19.

Em sua narrativa, Rosa, se mostra assustada com a pandemia. Nesse sentido, assinala:

No início eu pensei que talvez não fosse aquilo tudo que as pessoas estavam falando, uma vez que era uma realidade distante da minha, afinal o vírus estava na China, isso no fim de 2019, fiz tantos planos, idealizei um ano melhor em 2020, se soubesse que o mundo entraria nessa dificuldade toda teria pedido para que o ano de 2019 voltasse ao início. Bom o ano começou e com ele o vírus foi crescendo mundo a fora, e então chegou ao nosso País, continuei esperançosa afinal tínhamos os exemplos de como proceder diante desta doença por ter como exemplo os outros países, doce engano.

Em seu depoimento destaca que com:

a crise da saúde, a crise política, diante desde contexto e com os números de casos subidos veio a quarentena e a proibição de sair de casa livremente, um baque pra mim uma vez que eu me senti presa dentro de casa sem poder ir onde quero, pois tenho ansiedade e com esse isolamento sem poder sair de casa a ansiedade se intensificou, a preocupação com meus pais que já são idosos e moram longe, e com essa impotência de não ter uma proteção segura contra essa doença estão me fazendo ter crises de tristeza profunda, e nervosismo exacerbado, como uma pessoa que depende de outros para fazer algo dentro de casa e até mesmo fora dela e não ter como fazer da forma como gostaria estão me afetando emocionalmente, para não pirar estou me apoiando na minha Fé em Cristo, estou aproveitando para fazer algo que a muito tempo queria fazer, ler a Bíblia toda, a leitura sempre me fez bem, estou unindo o útil ao agradável!

Rosa, apresenta temor, ansiedade e tensão ao expressar:

O isolamento social a que fomos submetidos impediu que pudéssemos sair de casa, não poder ver gente, conversar com um amigo mais distante pessoalmente é algo pra mim insuportável, sou uma pessoa que necessita de estar com pessoas, socializar, talvez por anos da minha vida em casa sem muito contato social, quer saber bem da verdade, essa situação toda e essa ansiedade que estou passando nessa quarentena eu esteja revivendo

RIAEE - Revista Ibero-Americana de Estudos em Educação, Araraquara, v. 15, n. esp. 3, p. 2471-2489, nov., 2020. E-ISSN: 1982-5587 
sentimentos que vivi na minha infância que eu julgava estarem superados, mas com uma situação de estresse voltaram com toda força, ainda mais fortes que antes, agora terei que ter forças para superar mais essa dificuldade que diante de outras que as pessoas doentes estão passando é pequena.

A era que estamos vivendo tirou o direito de ir e vir de todas as pessoas. Mesmo não estando presa, tolhida de liberdade, somos aconselhados a ficar em casa, isolarmos, nos recolhermos com um medo comum: o vírus que vem assolando o planeta nos últimos meses. Em relação às Pessoas com Deficiência, esse isolamento parece se tornar mais acentuado ainda, uma vez que nos envolvemos menos com a rede mundial de computadores, assistimos poucos filmes, utilizamos menos o celular em Instagram, Facebook, Twitter, lemos menos livros disponíveis ao nosso alcance, cujos acessos para esses sujeitos são mais restritos.

Nessa narrativa, a entrevistada revela que:

a lição que tiro dessa situação toda, é que temos de dar mais valor as coisas simples da vida, não é um bem material que mais importa e sim as relações sociais que vivemos, é o abraçar, estar junto de quem amamos e que todo segundo importa em nossa vida.

Em seu depoimento escrito, Rosa acentua que:

Quando tudo isso amenizar, pois não voltaremos ao normal de antes nunca mais, quero dizer tudo o que deixei de dizer assim de perto olho no olho, a partir de agora desejo que todos repensem suas ações e vejam que o que mais importa não é o bem material e sim o bem que fazemos aos outros, a felicidade e o amor.

\section{Lírio}

O sujeito inicia sua narrativa, afirmando que:

o ano de 2020, iniciava cheio de muitas expectativas, sonhos e realizações pessoais, sociais e profissionais. Um novo fenômeno mudou bruscamente essa expectativa, uma vez que a capacidade de transmissão da doença tem proposto desafios fisicos e emocionais para população, em especial as Pessoas com Deficiência visual.

Desse modo, a sociedade por meio de medidas de isolamento, quarentena e distanciamento social, propõe que as pessoas em estado de vulnerabilidade se mantenham afastadas do convívio social. O sujeito com deficiência expressa em sua narrativa os momentos de incertezas que estamos vivendo em tempos de pandemia, em especial, considerando que é deficiente visual. Medo, insegurança, incapacidade de reação frente aos efeitos da pandemia se fazem presente na narrativa escrita do sujeito, não apenas em relação àqueles que tem deficiência, mas também outros que estão no grupo de risco.

RIAEE - Revista Ibero-Americana de Estudos em Educação, Araraquara, v. 15, n. esp. 3, p. 2471-2489, nov., 2020. E-ISSN: 1982-5587 
Em nossa análise, é profícuo assinalar que o Conselho Nacional de Saúde (BRASIL, 2020) expediu no dia 30 de abril de 2020 a Recomendação $N^{\circ} 31$, medidas com recomendações emergenciais complementares com objetivos de garantir os direitos e proteção social às Pessoas com Deficiência no contexto da Covid-19, especificamente postulando os direitos quanto ao atendimento das Pessoas com Deficiência e com doenças raras, o que inclui pessoas com transtorno do espectro autista.

Embora um número considerável de Pessoas com Deficiência pertença ao grupo de alto risco ao Novo Corona Virus - em virtude do quadro de doenças pré-existentes - o poder público pouco tem feito para fornecer as orientações e apoio necessários durante a atual pandemia.

Lírio faz críticas ao poder público ao mencionar as poucas ações dispensadas aos sujeitos com deficiência, em relação principalmente a proteção desses sujeitos que são mais vulneráveis.

Em sua narrativa, Lírio faz críticas ao atual sistema governamental afirmando:

É fato que as Pessoas com Deficiência em nosso país enfrentam maior dificuldade de ter acesso à saúde em razão da dificuldade de locomoção, de falta de autonomia, da inacessibilidade dos transportes público e da inacessibilidade de informação, dentre outras barreiras atitudinais e fisicas.

Nessa narrativa, Lírio critica as instituições públicas, observando o quanto essas cuidam mal dos seus cidadãos, em especial, os que estão em grupo de risco.

$\mathrm{O}$ isolamento social causado pela pandemia, à qual fomos submetidos vem nos causando espanto, temor, insegurança, considerando que mesmo havendo a liberdade, estamos presos, impedido de circular livremente, como, por exemplo, ir à escola, ao clube, à praça, ao bosque.

Lírio apresenta algumas dificuldades das Pessoas com Deficiência, no sentido de se locomover nos espaços sociais que não são inclusivos, afirmando que:

Medidas de contenção, como distanciamento social e isolamento pessoal, podem ser impossiveis para quem precisa de apoio do tato, da bengala para se locomover. Esses entraves que obstaculiza a autonomia e independência da Pessoa com Deficiência visual, tem forçado os sujeitos com deficiência ficarem em quarentena, isolamento e distanciamento das pessoas inclusive de entes queridos como familiares. Quanto ao trabalho buscamos fazer nossas atividades funcionais por meio de serviços remotos para evitar o máximo de aglomerações, apesar da falta de acessibilidade nestas ferramentas propostas para o desenvolvimento de nossas funções empregatícias.

O sujeito em seu depoimento tece ferrenhas críticas à gestão pública, denunciando a ausência do mesmo na proteção dos mais vulneráveis, como: sujeitos com deficiência visual, 
que faz uso das mãos para reconhecer os espaços ao seu redor; surdos, que fazem leitura labial, mas tem usar máscaras de proteção; e sujeitos com deficiência física, que utilizam-se das mãos para conduzir muletas e cadeiras de roda.

O sujeito com deficiência visual apresenta insegurança em relação ao medo da contaminação do Covid-19. Dessa forma, acentua: "Ademais, o medo e a insegurança permeiam sobre nós, pois ciente de nossas vulnerabilidades, buscamos sempre seguir as orientações de protocolo da Organização Mundial de Saúde". A narrativa do sujeito com deficiência, embora reconhecendo as orientações da OMS em relação aos cuidados com o Novo Corona Vírus, diz que as Pessoas com Deficiência ainda estão menos protegidas que os demais, uma vez que os espaços por onde circulamos não são acessíveis.

No que concerne ao trabalho remoto, Lírio revela a dificuldade, bem como a insegurança, desses sujeitos com deficiência em relação às plataformas digitais disponibilizadas para exercer atividades empregatícias. Ao se referir aos professores com deficiência visual, esses enfrentam exatamente o mesmo dilema, dar aulas em ambiente totalmente virtual, dada a inacessibilidade dos sistemas, a falta de orientações quanto a equipamentos que melhor atendam aos requisitos para as filmagens destas aulas, estrutura necessária quanto a webcam com foco automático, dentre outras necessárias para que estas pessoas tenham, efetivamente, igualdade de oportunidades.

Nas ruas, o deslocamento das Pessoas com Deficiência visual tornou-se tão arriscado quanto a própria doença, uma vez que as pessoas agora estão com medo de prestar auxilio numa travessia de avenidas, as quais representam um perigo, uma vez que as cidades não dispõem de sinais sonoros. Nestes dias em que a máscara se tornou um novo normal, a vulnerabilidade das Pessoas com Deficiência notadamente visual é ainda mais evidente. Ao se relacionar com o outro, notadamente um estranho, estas pessoas não sabem se estas estão utilizando o acessório, se ele é efetivo para sua proteção e a proteção da pessoa que a está utilizando.

Em sua narrativa, Lírio teme o contágio do vírus, pois não é possível saber se as pessoas ao seu redor estão usando equipamentos de proteção.

Lírio em seu depoimento, tece diversas críticas ao poder público, destacando o descompromisso deste para com os cidadãos. Nesse sentido, expressa:

$\mathrm{Na}$ relação com as empresas, notadamente as concessionárias de serviço público, nota-se o pouco compromisso, a má vontade, a ausência de uma política institucional com estes cidadãos. Todavia, as Pessoas com Deficiência visual têm sentido todo o peso de uma ausência de politicas públicas destinadas a dar, efetivamente, igualdade de oportunidade para estes cidadãos. Para que isto ocorra, é necessário que todas as pessoas com ou sem deficiência se mobilizem, exerçam pressão sobre nossas autoridades

RIAEE - Revista Ibero-Americana de Estudos em Educação, Araraquara, v. 15, n. esp. 3, p. 2471-2489, nov., 2020. E-ISSN: 1982-5587 
constituidas, demonstrem para a sociedade que a principal barreira a ser removida está dentro de cada um dos seus componentes.

Em uma perspectiva sociológica, cumpre-nos acentuar que a rotina diária, o isolamento social, o recolhimento em casa que estamos vivendo atualmente em tempos de pandemia, as vezes nos causa um certo temor, considerando que enquanto seres humano fomos constituídos para viver em grupo, interagindo, dialogando, se comunicando com nossos familiares, amigos próximos, colegas de trabalho, enfim, mantendo a convivência social.

\section{Notas Finais}

O cotidiano forçado que estamos vivendo em tempos de pandemia, o isolamento social em casa, o poder tocar as mãos nas pessoas que gostamos, admiramos, amamos. O beijo carinhoso no rosto daqueles seres que estão a nossa volta, a abstinência do caloroso abraço no momento do encontro, [...] nos fez mergulhar em um mundo frio, diferente, muito estranho, ladeado de (In)certezas; (Des)confianças; (Des)esperanças.

No que concerne as Pessoas com Deficiência, o fenômeno do isolamento social parece nos assustar mais ainda. Esse temor ocorre, por exemplo, em relação aos sujeitos com deficiência visual, considerando que o $(\mathrm{Re})$ conhecimento dos espaços a nossa volta se dá pelo toque com as mãos, uma vez que o mundo que nos ladeia não é inclusivo. Ao se referir às pessoas surdas que se comunicam apenas pela leitura labial, as máscaras colocaram fim a comunicação desses com os ouvintes, ou mesmo com os colegas surdos.

No que se refere aos sujeitos com deficiência física, o temor também se faz presente, uma vez que, esses se apoiam em corrimãos, banco do metrô, poltrona do coletivo, portas, maçanetas... para se locomover nos espaços sociais que não são inclusivos. O medo de contaminar, nós e aos outros, seguramente contribui para que nosso isolamento social se torne mais acentuado ainda. Embora velado, esse temor também se registra porque há na e entre as pessoas processos de discriminação, estereótipos estigmas com medo de serem contagiadas.

No cenário planetário, a situação estranha que ora se desenha nos incomoda, na medida em que em todos os tempos e espaços deparamos com pessoas mascaradas, com rostos, bocas, narizes encobertos. Não podemos mais "Ver" o sorriso nos lábios no momento do (re)encontro, o semblante alegre ao anoitecer, o brilho nos olhos ao amanhecer.

As máscaras criaram barreiras, muros, isolamentos entre nós e os outros; nos afastaram das pessoas que gostamos, admiramos e até amamos; o medo desse temido vírus nos isolou, 
nos deixou mais frios; a necessidade do isolamento social fez com que nos tornássemos mais individualistas, egoístas talvez.

Ao se referir às Pessoas com Deficiência visual, que por sinal são os três autores desse manuscrito, estamos (Re)vestidos literalmente por duas máscaras. Uma porque somos (des)providos da visão imagética dos objetos que pairam à nossa frente. A outra porque as máscaras impediram-nos de nos aproximar daqueles que amamos nos diversos espaçostempos, como crianças nos orfanatos, pessoas encarceradas, participação nos templos religiosos e idosos nos abrigos.

Enfim, estamos vivendo uma "Nova Era", nos mesmos espaçostempos, porém, separados, isolados, distantes de quem gostamos, admiramos, até amamos. O ano de 2020, está nos fazendo ser diferentes com comportamentos estranhos, não sei, mais egoísta, claro, não porque queremos, mas porque a situação que ora se desenha no planeta vêm nos levando a isso.

\section{REFERÊNCIAS}

AMADO, J. O Grande Mentiroso: tradição, veracidade e imaginação em História oral. História. São Paulo, n. 14, 1995.

AMARAL, L. A. Integração Social e Suas Barreiras: representações culturais do corpo mutilado. Revista de Terapia Ocupacional, São Paulo, v. 2, n. 4, p. 188-195, 1991.

BENJAMIN, W. O narrador: considerações sobre a obra de Nikolai Leskov. In: BENJAMIN, W. Magia e técnica, arte e política: ensaios sobre literatura e história da cultura. São Paulo: Brasiliense, 1994.

BIANCHETTI, L. Um olhar sobre a diferença: as múltiplas maneiras de olhar e ser olhado e suas decorrências. Revista brasileira de educação especial, Marília, v. 8, n.1, p. 1-8, 1995. Disponível em:

https://www.abpee.net/homepageabpee04_06/artigos_em_pdf/revista8numero1pdf/1bianchett i.pdf. Acesso em: 10 jun. 2020.

BRASIL. Conselho Nacional de Saúde. Recomendação no 31, de 30 de abril de 2020. Recomenda medidas emergenciais complementares que visam a garantia dos direitos e da proteção social das Pessoas com Deficiência no contexto da Covid-19. Brasília, Distrito Federal, 2020. Disponível em: https://conselho.saude.gov.br/recomendacoes-cns/1146recomendacao-n-031-de-30-de-abril-de-2020. Acesso em: 01 ago. 2020.

BUENO, B. O. O método autobiográfico e os estudos com histórias de vida de professores: a questão da subjetividade. Educação e Pesquisa, São Paulo, v.28, n.1, p. 11-30, jan./jun. 2002. Disponível em: http://www.scielo.br/pdf/ep/v28n1/11653.pdf. Acesso em: 10 maio 2020. 
CATROGA, Fernando. Memória e História. In: PESAVENTO, S. J. (Org.). Fronteiras do Milênio. Porto Alegre: Editora da Universidade/UFRGS, 2001.

CERTEAU, Michel de. A invenção do cotidiano. Editora Vozes: Petrópolis 1994.

CLANDININ, D. J.; CONNELLY, F. M. Pesquisa narrativa: experiências e história na pesquisa qualitativa. Trad. Grupo de Pesquisa Narrativa e Educação de Professores ILEEL/UFU. Uberlândia: EDUFU, 2011.

CORREIA, L. M. Alunos com necessidades educativas especiais nas classes regulares. Porto: Porto Editora, 1999.

HALL, Stuart. Identidade cultural na pós-modernidade. 3. ed. Rio de Janeiro: DP\&A, 1999.

MARQUESIN, D. F. B.; FERRAGUT, L. F. Narrativa como objeto de estudo: aportes teóricos. Revista Múltiplas Leituras, v. 2, n. 2, p. 219-237, jul./dez. 2009. Disponível em: https://www.metodista.br/revistas/revistasmetodista/index.php/ML/article/viewFile/1450/1475. Acesso em: 10 maio 2020.

MISÉS, R. A criança deficiente mental: uma abordagem dinâmica. Rio de Janeiro: Zahar, 1977

MOITA, M. C. Percursos de Formação e de Trans-Formação. In: NÓVOA, A. A vida de professores. Porto: Porto Editora, 1995.

QUEIROZ, M. I. P. Variações sobre a técnica de gravador no registro da informação viva. São Paulo: Ed. T A Queiroz, 1991.

RADABAUGH, M. P. Director IBM National Support Center for Persons with Disabilities. 1988.

ROCHA, L. P.; REIS, M. B. F. A pesquisa narrativa em educação especial. Revista IberoAmericana de Estudos em Educação, Araraquara, v. 15, n. esp. 1, p. 884-899, maio 2020. DOI: https://doi.org/10.21723/riaee.v15iesp.1.13500

SENA, F. C.; ALBUQUERQUE, J. T. P. J. Processos identitários de docentes universitários: espaço e tempo da formação. Revista Ibero-Americana de Estudos em Educação, Araraquara, v. 15, n. esp. 2, p. 1585-1599, ago. 2020. DOI:

https://doi.org/10.21723/riaee.v15iesp2.13831

SOUZA, E. C. Pesquisa narrativa e escrita (auto) biográfica: interfaces metodológicas e formativas. In: SOUZA, E. C.; ABRAHÃO, M. H. M. B. (Org.). Tempos, narrativas e ficções: a invenção de si. Porto Alegre: EDIPUCRS, 2006.

SOUZA, E. C. (Auto)biografia, histórias de vida e práticas de formação. In: NASCIMENTO, A. D.; HETKOWSKI, T. M. (Org.). Memória e formação de professores [online]. Salvador: EDUFBA, 2007. 
VILARONGA, I. “Olhares Cegos": A Audiodescrição e a Formação de Pessoas com Deficiência Visual. In: MOTTA, L. M. V. M.; ROMEU FILHO, P. (Org.). Audiodescrição transformando Imagens em palavras. São Paulo: Secretaria dos Direitos da Pessoa com Deficiência do Estado de São Paulo, 2010.

\section{Como referenciar este artigo}

COSTA, V. B.; BATISTA, C. P.; TAVARES, E. R. B. Narrativas de sujeitos com deficiencia e isolamento social em tempos de pandemia. Revista Ibero-Americana de Estudos em Educação, Araraquara, v. 15, n. esp. 3, p. 2471-2489, nov., 2020. E-ISSN: 1982-5587. DOI: https://doi.org/10.21723/riaee.v15iesp3.14452

Submetido em: 13/08/2020

Revisões requeridas em: 30/08/2020

Aprovado em: 29/09/2020

Publicado em: 30/10/2020 